\title{
The Role of Social Media in Spreading Terror and How Religion treats it
}

\author{
Mona Alinize, $\mathrm{PhD}$ \\ Community College, Rafha Branch \\ Northern Border University
}

\author{
Najwa Shehadeh Altabeiri \\ Ministry of Education \\ Jordan Master Degree
}

\begin{abstract}
We will talk about the tremendous progress of communications network recently which enhance the spreading of terror through the social media like Facebook, you tube, and twitter which considered the most popular social media. Terror these days differ from the traditionally known terror, since the terrorist groups spreading their ideas and opinions, and recruitment people through that network. Islamic values spreading through these media and activation the role of youth in fighting terror.
\end{abstract}

\section{Keywords}

Social media

\section{INTRODUCTION}

The social network has played a serious role in spreading of the phenomenon of terror among those groups. With the progress of modern means of communications especially in the recent years, most notably face book, twitter, you tube, Instagram, and what's up and other fast and unlimited media. Social networking is a global network imposes in Arab societies, and so it is available and free of charge, and we will find most of the youth using the network to get important information about anything anytime anywhere and chat with anyone anywhere in the media which led to the publication of ideas and opinion of anyone. This lead to lots of free time that make them easy to lag behind the terror groups and becoming a member of them.

Thos make the social media rolling a serious role in terror and execute terrorism operation through the world.

\section{SOCIAL MEDIA NETWORK DEFINITION}

It is the term indicates the existing sites on the internet which allow communicating between their users in the life's, community according to their interest or affiliates (university, country, religion, etc)and it occurred by direct communication. The goals of those sites differ from each other, some for puplic commi=niceties and making friends, others for to make social network limited field like proffering, artiest, Web bids.

\subsection{Defines the Social Media As}

An expression used to describe any site on the internet which allows to the users making personal and the public page, which led to making personal relations between the users that page.

There are statistic in the internet with more than 420 social network who cares about the forum and blogs such as Facebook, twitter, including storing images and retransmitting such as flicker, including what published video YouTube and some of which offer, applications for some big companies to support social through and participation with the site's users such as Google, yahoo, and others.

There are also other services and technologies concerned with the exchange and sharing between the users and we will learn about those sites including:

\subsubsection{Facebook}

It considered being the most affecting site in the world, although it is 10yaers old. Mark Zuckerberg student in Harvard has invented the face book since February 2004. It was for the university student only then expands to the whole world, now face book has 880 million users in the social media.

Mark Zuckerberg sees that the face book can replace internet and emails since the users can chat, send messages and picture through the face book.

Egypt considered the first in the Middle East since it has 15million, then Saudi Arabia which has7million

Ranking of Arab countries in terms of Facebook users september 2012

\begin{tabular}{|c|c|c|c|c|}
\hline $\begin{array}{c}\text { World } \\
\text { ranking }\end{array}$ & Country & Number of subscribers & $\begin{array}{c}\text { Increase over the } \\
\text { previous year }\end{array}$ & Percentage of increase \\
\hline 21 & Egypt & 11.472 .400 & 983.820 & $\% 9.39$ \\
\hline 32 & saudia Arabia & 5.240 .720 & 97.080 & $\% 1.89$ \\
\hline 37 & Morocco & 4.764 .560 & 338.240 & $\% 7.67$ \\
\hline 43 & Algeria & 3.736 .440 & 407.880 & $\% 12.25$ \\
\hline 47 & Tunisia & 3.157 .860 & 204.060 & $\% 6.90$ \\
\hline 48 & $\begin{array}{c}\text { Enited Arab } \\
\text { Emirates }\end{array}$ & 3.078 .000 & 168.140 & $\% 5.78$ \\
\hline n / a & Syria & 2.932 .680 & --- & -- \\
\hline 56 & Jordan & 2.456 .100 & 232.100 & $\% 10.43$ \\
\hline 62 & Iraq & 2.087 .760 & 536.220 & $\% 34.58$ \\
\hline 71 & Lebanon & 1.519 .660 & 78.660 & $\% 5.54$ \\
\hline n / a & Sudan & 1.440 .740 & ---- & - \\
\hline 81 & Palestine & 1.012 .980 & 95.760 & $\% 10.47$ \\
\hline 86 & Kuwait & 772.440 & -127.520 & $\%-14.19$ \\
\hline 89 & Qatar & 699.420 & 126.600 & $\% 44.99$ \\
\hline 95 & Libya & 633.640 & 168.960 & $\% 36.36$ \\
\hline 96 & Yemen & 576.500 & 140.420 & $\% 32.20$ \\
\hline 102 & Amman & 485.140 & 63.780 & $\% 15.11$ \\
\hline 110 & Bahrain & 355.500 & 10.620 & $\% 3.07$ \\
\hline & Total & 46.422 .540 & 3.524 .820 & N A \\
\hline
\end{tabular}

\subsubsection{Twitter}

Twitter is a small site of those sites since you can send and 
read comments which not exceed 140 letters for the one message, which called tweet. Twitter established by jack piracy since October 2006.

Twitter is very fast since the tweets on the first day were 200 million.

You will notice the big difference between the numbers of users according to the population number

Example: you will find the highest percentage in UAE and Qatar since the low number of population.

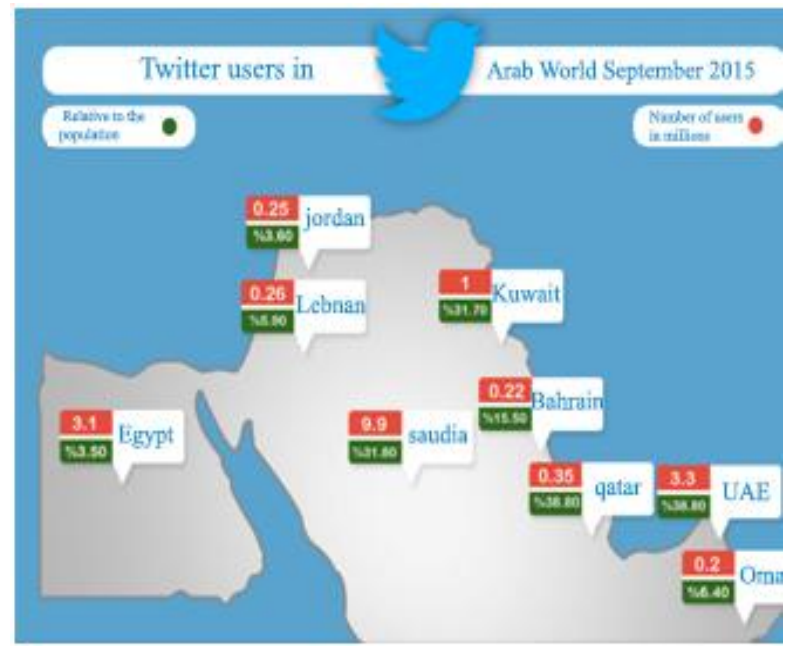

Social network considered as a good tool gives privacy and confidentiality to its users and this for
a. Ability to communicate with anyone
b. Privacy
c. Youth acceptance
d. Lack of control
e. Lot of intellectual sites
f. Extreme forum

Terror practice and some concepts:

The revolution of social media leads to a lot of terror concepts

- Egyptian law definition:

It is using violence or a threat to anyone for individual crime or group crime which leads to:

- Harm or risk any one life

- Damage the environment or community or transportation or buildings

- Forbidden worshipping or work of science institute

The Arabic for antiterrorism definition:

It is every action threat whatever it is motivated or purposes that occur in implementation of the project of social individually or collectively and aims to spread horror among the peoples or intimidate their life, liberty, or security risk or harm the environment facilities

Justin Paul gives another definition:

1. Authority terror: the authority against its people

2. Oppressed terror: gangs war by the people with no power or resources
3. Civil war terror: according to ti politic or religion conflict

Sabotage terror: police terror from outside

Terror in Islamic vision: in the holy Quran terror used to bring people back to the right and showed that terrorist is enemy for god and believers.

Social media site environment to recruitment terrorist:

The revolution in the internet serve the terror a special and accidentally service and used to spread their opinions and using people as members of those gangs according to:

1. Available Information

2. Incitemnet to Hater

3. Technology capabilities

Social media elements that serve terrorist groups:

1. Strict Confidentiality

2. Communication

3. Expenses

4. Information digging

5. Telecommunication

6. Information terror

7. Finance

8. Attack Another Terror Organization

Main goals of terror groups

1. Spread Ideas and Thoughts

2. Progress Coordination

3. Finance Support

4. Training the Terror Groups

Social media network considered a threat to the national security since it was the cause of collapse of the regimes in Syria, Egypt and Libya, since it influence the public opinion according to:

1. Terror definition and its relation with society: the role of social media in enhancing terror

2. Psychological war relation with social media: spreading psychological war plans

3. Targeting people with high position: using their day life information

4. Roumers: used to spread rumors.

Kingdom of Saudi Arabia depends on (Alriyadh document) which issued in 2016 in Al-Manama to fight the information crime, and it is considered as a law to fight the information technologies crime.

The penalty up to 5 years in jail and 2 million SR as a violation or both.

KSA role in terror fight:

1. Maintain faith

2. Refuse all types of terror

3. Maintain the national security 
4. Maintain the international security

5. KSA interest in treaties and conventions

6. Islamic practice

7. Scientist altitude against terror

Arabic countries interest to fight terror

\section{CONCLUSION}

Terror using social media is world wide and occupies people minds. ISIS is one of the terrorist groups which established Islamic state in Syria and Iraq, and the role of the true Islamic faith in fighting it.

1. Activate advocacy sites to face the negative results by:
A. Invite youth
B. Establishes sites and invites all
C. Using internet to build advocacy sites

2. Recommendation to face terror idea:
A. Block extreme sites
B. Using the internet to earn good science
C. KSA gives a lot effort to face terror

3. Reinforce the family role
A. Fulfill youth security demands
B. Youth chasing

4. Facing electronic crimes
A. Develop a system to avoid crimes
B. Devolop the criminal law
C. Challenge the law nature.

\section{REFERENCES}

[1] http://www.middle-east-online.com/?id=185007

[2] http://www.majalla.com/arb/2014/08/article55251987

[3] http://almogaz.com/news/politics/2014/06/03/ 150682

[4] http://www.24.ae/Article.aspx?ArticleId= 8256:

[5] http://alshahedkw.com/index.php?option=com_content\& view=article\&id=90041:2013-03-27-18-0951\&catid $=31: 03 \&$ Itemid $=419$

[6] http://www.alarab.co.uk/?id=23430

[7] Scientific Study of Religion, 15, 29-45. Batson, C. D., Lishner, D. A., Carpenter, A., Dulin, L., HarjusolaWebb, S., Stocks, E. L., et al. (2003). ".As you would have them do unto you": Does imagining yourself in the other's place stimulate moral action? Personality and Social Psychology Bulletin, 29, 1190-1201. Batson, C. D., Oleson, K. C., Weeks, J. L.

[8] Anderson, B. W. (1998). Understanding the Old Testament. Upper Saddle River, NJ: Prentice Hall. Atran, S., \& Henrich, J. (2009). The evolution of religion. Manuscript submitted for publication. Barrett, J. L. (2004). Why would anyone believe in God? Walnut Creek, CA: AltaMira Press. Batson, C. D. (1976). Religion as prosocial: Agent or double agent? 